This is the author's final, peer-reviewed manuscript as accepted for publication. The publisher-formatted version may be available through the publisher's web site or your institution's library.

\title{
Pharmacokinetics and milk secretion of gabapentin and meloxicam co-administered orally in Holstein-Friesian cows
}

Pradeep R. Malreddy, Johann F. Coetzee, Butch KuKanich, and Ronette Gehring

\section{How to cite this manuscript}

If you make reference to this version of the manuscript, use the following information:

Malreddy, P. R., Coetzee, J. F., KuKanich, B., \& Gehring, R. (2013). Pharmacokinetics and milk secretion of gabapentin and meloxicam co-administered orally in HolsteinFriesian cows. Retrieved from http://krex.ksu.edu

\section{Published Version Information}

Citation: Malreddy, P. R., Coetzee, J. F., KuKanich, B., \& Gehring, R. (2013). Pharmacokinetics and milk secretion of gabapentin and meloxicam co-administered orally in Holstein-Friesian cows. Journal of Veterinary Pharmacology and Therapeutics, 36(1), 14-20.

Copyright: ( 2012 Blackwell Publishing Ltd

Digital Object Identifier (DOI): doi:10.1111/j.1365-2885.2012.01384.x

Publisher's Link:

http://onlinelibrary.wiley.com/doi/10.1111/j.1365-2885.2012.01384.x/full

This item was retrieved from the K-State Research Exchange (K-REx), the institutional repository of Kansas State University. K-REx is available at http://krex.ksu.edu 


\section{List of Abbreviations:}

\section{Pharmacokinetic Parameters}

$\lambda_{z}$ : First-order elimination rate constant

$t_{1 / 2 \lambda z}:$ Terminal (elimination) half-life

$T_{\max }$ : Time to maximum plasma concentration

$C_{\text {max }}:$ Maximum plasma concentration

$C_{0}$ : Initial plasma concentration extrapolated to time zero

$\mathrm{AUC}_{\text {0-t: }}$ Area under curve from time zero to time of last measured concentration

$\mathrm{AUC}_{0-\infty}:$ Area under curve from time zero to infinity

$\mathrm{AUMC}_{0-\infty}:$ Area under the first moment curve from time zero to infinity

$\mathrm{Cl} / \mathrm{F}$ : Plasma clearance corrected for unknown bioavailability

MRT: Mean residence time

\section{Pharmacokinetic Parameters specific for Milk}

$\mathrm{CL}_{M} / \mathrm{F}$ : Milk Clearance (volume of blood cleared of drug per unit time by passing into the milk) corrected for unknown bioavailability

Percent $_{\text {recovered: }}$ Cumulative amount of drug eliminated through milk expressed as a percentage of the administered dose

\section{Other Abbreviations}


MER: Milk drug excretion rate

MRL: Maximum Residue Limit

M/P: Milk to plasma ratio

SPE: Solid phase extraction

LOQ: Limit of quantitation

GABA: Gamma amino butyric acid

NSAID: Non-steroidal anti-inflammatory drug

SD: Standard deviation

P.O: Per oral 
1 Title: Pharmacokinetics and milk secretion of gabapentin and meloxicam co-

2 administered orally in Holstein-Friesian cows.

3 Short Title: Milk secretion of gabapentin and meloxicam in dairy cattle.

4 Authors:

5 Pradeep R. Malreddy ${ }^{a}$, Johann F. Coetzee ${ }^{c}$, Butch KuKanich ${ }^{b}$, and Ronette Gehring ${ }^{a}$

$6 \quad{ }^{a}$ Department of Clinical Sciences

7 bepartment of Anatomy and Physiology

8 Kansas State University College of Veterinary Medicine

9 Manhattan, KS 66506

10

11 Department of Veterinary Diagnostic and Production Animal Medicine

12 lowa State University College of Veterinary Medicine

13 Ames, IA 50011

14

15 Correspondence:

16 Pradeep Malreddy

17 Department of Clinical Sciences

18 Q-214 Mosier Hall

19 College of Veterinary Medicine

20 Kansas State University

21 Manhattan, KS 66506

22 E-mail: rgehring@vet.k-state.edu

23 Fax: (785) 532-2252 


\section{Abstract}

Management of neuropathic pain in dairy cattle could be achieved by combination therapy of gabapentin, a GABA analog and meloxicam, an NSAID. This study was designed to determine specifically the depletion of these drugs into milk. Six animals received meloxicam at $1 \mathrm{mg} / \mathrm{kg}$ and gabapentin at $10 \mathrm{mg} / \mathrm{kg}$ while another group $(n=6)$ received meloxicam at $1 \mathrm{mg} / \mathrm{kg}$ and gabapentin at $20 \mathrm{mg} / \mathrm{kg}$. Plasma and milk drug concentrations were determined over 7 days post-administration by HPLC/MS

followed by non-compartmental pharmacokinetic analyses. The mean $( \pm$ SD) plasma $\mathrm{C}_{\max }$ and $\mathrm{T}_{\max }$ for meloxicam $(2.89 \pm 0.48 \mu \mathrm{g} / \mathrm{ml}$ and $11.33 \pm 4.12$ hours $)$ were not much different from gabapentin at $10 \mathrm{mg} / \mathrm{kg}(2.87 \pm 0.2 \mu \mathrm{g} / \mathrm{ml}$ and 8 hours $)$. The mean $( \pm \mathrm{SD})$ milk $\mathrm{C}_{\max }$ for meloxicam $(0.41 \pm 0.16 \mu \mathrm{g} / \mathrm{ml})$ were comparable to gabapentin at 10 $\mathrm{mg} / \mathrm{kg}$ (were $0.63 \pm 0.13 \mu \mathrm{g} / \mathrm{ml}$ and $12 \pm 6.69$ hours). The mean plasma and milk $\mathrm{C}_{\max }$ for gabapentin at $20 \mathrm{mg} / \mathrm{kg}$ P.O. were almost double the values at $10 \mathrm{mg} / \mathrm{kg}$. The mean $( \pm S D)$ milk to plasma ratio for meloxicam $(0.14 \pm 0.04)$ was lower than for gabapentin $(0.23 \pm 0.06)$. The results of this study suggest that milk from treated cows will have low drug residue concentration soon after plasma drug concentrations have fallen below effective levels. 
Introduction

Chronic pain associated with lameness is considered one of the most significant welfare concerns in dairy cows (Whay, Main et al. 2003). Hyperalgesia has been reported to persist in dairy cattle and lame sheep for at least 28 days after the causal lesion has resolved (Ley, Waterman et al. 1996; Whay, Waterman et al. 1998). Inflammatory pain associated with lameness responds modestly to treatment with nonsteroidal anti-inflammatory drugs (NSAIDs) (Whay, Main et al. 2003; Flower, Sedlbauer

et al. 2008) but neuropathic pain (due to nerve damage or neuronal dysfunction), very limited information for its occurrence in dairy cattle, is considered refractory to the effects of NSAIDs and many opioid analgesics (Woolf and Mannion 1999). Gabapentin (1-(aminomethyl) cyclohexane acetic acid) is a y-aminobutyric acid (GABA) analogue originally developed for the treatment of spastic disorders and epilepsy (Cheng and Chiou 2006). Subsequent studies have established that gabapentin is also effective for the management of chronic pain of inflammatory or neuropathic origin (Hurley, Chatterjea et al. 2002). Although the mechanism of action of gabapentin is poorly understood, it is thought to bind to the $\alpha 2-\delta$ subunit of voltage gated calcium channels acting pre-synaptically to decrease the release of excitatory neurotransmitters (Taylor 2009).

Gabapentin appears to be absorbed from the gastro-intestinal tract by a saturable amino-acid transporter system (Su et al., 1995). Plasma gabapentin concentrations $>2 \mu \mathrm{g} / \mathrm{mL}$ in humans are associated with a lower frequency of seizures (Sivenius, Kalviainen et al. 1991). Similar doses are used to treat epilepsy and neuropathic pain suggesting that these concentrations will also be effective for 
analgesia. It has also been reported that gabapentin can interact synergistically with NSAIDs to produce antihyperalgesic effects (Hurley, Chatterjea et al. 2002; Picazo, Castaneda-Hernandez et al. 2006).

Meloxicam is a NSAID of the enolic acid (oxicam) group that is considered to be non-specific cyclooxygenase inhibitor. However, studies from some laboratories show cyclooxygenase-2 selectively at low concentrations in humans (Lazer, Miao et al. 1997), rats (Ogino, Hatanaka et al. 1997), and dogs (Brideau, Van Staden et al. 2001). The plasma pharmacokinetics of meloxicam co-administered with gabapentin has been previously described in cattle (Coetzee, Mosher et al. 2010). Plasma gabapentin concentrations $>2 \mu \mathrm{g} / \mathrm{mL}$ were maintained for up to $15 \mathrm{~h}$ and meloxicam concentrations $>0.2 \mu \mathrm{g} / \mathrm{mL}$ for up to $48 \mathrm{~h}$. The pharmacokinetic profile of oral gabapentin and meloxicam supports clinical evaluation of these compounds for management of neuropathic pain in dairy cattle; however, information regarding the depletion of these compounds in milk is needed to determine when milk from treated animals is safe for human consumption.

\section{Materials and Methods}

\section{Animals}

Twelve clinically healthy Holstein-Friesian cows, free of mastitis were used in this study as determined by the examination of milk from each animal for gross abnormalities and acceptable level of somatic cell counts, which were in the acceptable range between $13,000-528,000$ cells $/ \mathrm{mL}$ (The maximum limit allowed is 750,000 per $\mathrm{mL}$ according to 
the U.S. Food and Drug Administration-2007 Pasteurized Milk Ordinance). The animals were aged between 34 and 62 months and weighed between 543 and $891 \mathrm{Kg}$ at the time of study. All cows were in their first, second or third lactation. Cows were maintained on a diet comprising a total mixed ration comprising, cottonseed, alfalfa hay, sweet bran and corn silage with ad-libitum water at Kansas State University Dairy Farm.

\section{Animal Phase Study Design}

The animals were randomly assigned to two treatment groups comprising 6 animals per group. One group was co-administered gabapentin (400 mg and $100 \mathrm{mg}$ capsules, Actavis Elizabeth LLC, Elizabeth, $\mathrm{NJ}$ ) and meloxicam (15 mg tablets, Unichem Pharmaceuticals, Rochelle Park, $\mathrm{NJ}$ ) at a dose of $10 \mathrm{mg} / \mathrm{kg}$ and $1 \mathrm{mg} / \mathrm{kg}$ respectively. The second group received gabapentin and meloxicam at a dose of $20 \mathrm{mg} / \mathrm{kg}$ and 1 $\mathrm{mg} / \mathrm{kg}$ respectively. The drugs were combined in a gelatin capsule and delivered orally with a balling gun into the oropharynx.

\section{Milk and Blood Sample Collection}

Twenty milliliters of milk were collected in polycarbonate bottles from each cow just before drug administration and then every 8 hours coinciding with the milking schedules at the dairy farm for 7 days. The samples were collected from the collection vessel once milking of the cow was completed. The milk from these cows was not added to the bulk tank in order to prevent drug residues from entering the human food chain. The volume of milk produced at each milking by each individual cow was also recorded at the time of sample collection. The samples were immediately brought back to the lab and frozen at $-80^{\circ} \mathrm{C}$ until further analysis. 
113 At each milk sampling time, $10 \mathrm{ml}$ of blood were collected by venipuncture of the jugular

114 vein and transferred to heparinized vacutainers. A set of blood samples was also

115 collected prior to drug administration to confirm that animals did not have previous

116 exposure to the test compounds. Blood samples were immediately brought back to the

117 lab, centrifuged at $1500 \mathrm{~g}$, the plasma transferred to cryovials, and stored at $-80^{\circ} \mathrm{C}$ until

118 further analysis.

119 Milk Sample Preparation and HPLC/MS analysis

120 Milk samples were prepared by adding $0.2 \mathrm{~mL}$ of the sample or milk standard to $0.1 \mathrm{~mL}$

121 of the internal standard solution containing $1 \mu \mathrm{g} / \mathrm{mL}$ of piroxicam (MP Biomedicals,

122 Solon, OH, USA) and $1 \mu \mathrm{g} / \mathrm{mL}$ of pregabalin (Lyrica, Pfizer, Inc., NY, NY, USA).

123 Trichloracetic acid $0.2 \mathrm{~mL} 30 \%$ in water, was added and then the solution was vortexed

124 for 5 seconds. The samples were centrifuged for 5 minutes at $15,000 \times g$ and then the

125 analytes were extracted from supernatant using solid phase extraction cartridges (SPE,

126 Varian Bond Elute C18, Varian Inc. Palo Alto, CA). The SPE were conditioned with 1

$127 \mathrm{~mL}$ methanol followed by $1 \mathrm{~mL}$ of water and then $0.35 \mathrm{~mL}$ of the sample supernatant

128 was added. The SPE were washed with $1 \mathrm{~mL}$ de-ionized water and the analytes eluted

129 with $1 \mathrm{~mL}$ methanol. The eluate was evaporated to dryness under an air stream at 40

$130{ }^{\circ} \mathrm{C}$ and then reconstituted with $0.2 \mathrm{~mL} \mathrm{50 \%} \mathrm{methanol} \mathrm{and} \mathrm{vortexed} \mathrm{for} 5$ seconds. The

131 solution was centrifuged for 5 minutes at $15,000 \times \mathrm{g}$ to sediment particulates and 0.020

$132 \mathrm{~mL}$ was injected onto the HPLC. Milk standards were made by adding meloxicam (LKT

133 Laboratories, St. Paul, MN, USA) and gabapentin (Spectrum Chemicals, Gardena, CA,

134 USA) to untreated milk at $0,10,20,50,100,200,500,1000$, and $2000 \mathrm{ng} / \mathrm{mL}$ each. The

135 linear standard curve was accepted if the predicted values were within $15 \%$ of the 
actual values and the correlation coefficient $(R)$ was at least 0.99 . The LOQ of the assay for meloxicam and gabapentin in milk was $10 \mathrm{ng} / \mathrm{mL}$ and defined as the lowest concentration of the linear standard curve with a predicted value within $15 \%$ of the actual value with an $\mathrm{R}$ of at least 0.99 . The accuracy was $99 \pm 6 \%$ of the actual concentration and the coefficient of variation was $6 \%$ determined on replicates of 4 each at 10,100 , and $2000 \mathrm{ng} / \mathrm{mL}$ for gabapentin in milk. The accuracy was $97 \pm 3 \%$ of the actual concentration and the coefficient of variation was $2 \%$ determined on replicates of 4 each at 10,100 , and $2000 \mathrm{ng} / \mathrm{mL}$ for meloxicam in milk.

\section{Plasma Sample Preparation and HPLC/MS Analysis}

Plasma samples were prepared by adding $0.05 \mathrm{~mL}$ of plasma or plasma standard to 0.2 $\mathrm{mL}$ of internal standard solution containing $250 \mathrm{ng} / \mathrm{mL}$ of piroxicam and gabapentin in methanol with $0.1 \%$ formic acid. The samples were vortexed for 5 seconds and then centrifuged for 10 minutes at $15,000 \times \mathrm{g}$. The supernatant was transferred to an injection vial with the injection volume being $0.020 \mathrm{~mL}$. Plasma standards were made by adding meloxicam and gabapentin to untreated plasma at $0,25,50,100,200,500$, 1000 , and $5000 \mathrm{ng} / \mathrm{mL}$ each. The linear standard curve was accepted if the predicted values were within $15 \%$ of the actual values and the correlation coefficient $(R)$ was at least 0.99 . The $L O Q$ of the assay for meloxicam and gabapentin in plasma was 25 $\mathrm{ng} / \mathrm{mL}$ and defined as the lowest concentration of the linear standard curve with a predicted value within $15 \%$ of the actual value with an $R$ of at least 0.99 . The accuracy was $96 \pm 5 \%$ of the actual concentration and the coefficient of variation was $5 \%$ determined on replicates of 4 each at 10,100 , and $2000 \mathrm{ng} / \mathrm{mL}$ for gabapentin in milk. The accuracy was $97 \pm 8 \%$ of the actual concentration and the coefficient of variation 
was $7 \%$ determined on replicates of 4 each at 50,500 , and $5000 \mathrm{ng} / \mathrm{mL}$ for meloxicam in plasma.

The plasma concentrations of gabapentin and meloxicam were simultaneously determined using liquid chromatography (Shimadzu Prominence, Shimadzu Scientific Instruments, Columbia, MD, USA) with mass spectrometry (API 2000, Applied Biosystems, Foster City, CA, USA). The mobile phase consisted of acetonitrile (mobile phase $A$ ) with $0.1 \%$ formic acid (mobile phase $B$ ) with a constant flow rate of 0.4 $\mathrm{mL} / \mathrm{min}$. A mobile phase gradient was used starting at $100 \% \mathrm{~B}$ from $0-1$ minutes, a linear gradient to $60 \%$ B at 3 minutes which was held until 5 minutes and then a linear gradient to $100 \%$ B at 5.5 minutes with a total run time of 8 minutes. A phenyl column

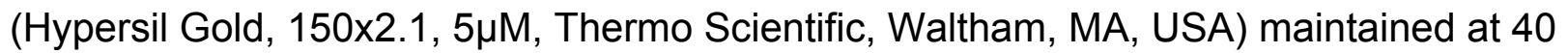
${ }^{\circ} \mathrm{C}$ achieved separation. The qualifying ion for meloxicam was 352.1 and the quantifying ion for meloxicam was 114.9. The qualifying ion for gabapentin was 172.1 and the quantifying ion for gabapentin was 154.1. The qualifying ion for piroxicam (meloxicam internal standard) was 332.1 and the quantifying ion for piroxicam was 95.1. The qualifying ion for pregabalin (gabapentin internal standard) was 160.0 and the quantifying ion for pregabalin was 142.0 . The source temperature was $350{ }^{\circ} \mathrm{C}$ and the ionization spray energy was $5000 \mathrm{~V}$. The curtain gas, gas 1 , and gas 2 flow rates were 10, 30, and 75 arbitrary units, respectively.

\section{Non-compartmental analysis of plasma and milk time-concentration data}

Non-compartmental pharmacokinetic analyses were performed using Excel (Microsoft, WA) add-in program, PK solver (Zhang, Huo et al. 2010) The various parameters 
estimated included area under the plasma time-concentration curve from time zero to

182 infinity $\left(\mathrm{AUC}_{0-\infty}\right)$, area under the first moment curve from time zero to infinity (AUMC),

183 first-order elimination rate constant $\left(\lambda_{z}\right)$, terminal half-life $\left(T_{1 / 2} \lambda z\right)$, mean residence time 184 (MRT), maximum plasma concentration $\left(\mathrm{C}_{\max }\right)$, and time to maximum plasma 185 concentration $\left(\mathrm{T}_{\max }\right)$.

\section{Milk excretion analysis}

187 The milk collection times, concentration and production data were fit to an excretion 188 model using Phoenix® WinNonlin ${ }^{\mathrm{TM}}$ (Pharsight Corporation, Mountain View, CA) to 189 calculate the milk drug excretion rate (MER) over the period using Equation 1.

$$
M E R=\Delta A / \Delta t=\frac{[C] \times \text { Volume }}{(\text { Ending time-Starting time })}
$$

\section{Equation 1}

Where MER is the Milk drug Excretion Rate between subsequent milk collections and 193 represents the amount of drug $(\Delta \mathrm{A})$ eliminated in the milk per unit time $(\Delta t),[C]$ is the 194 milk drug concentration, Ending time is the time of milk collection, and Starting time is 195 the time of collection of the previous milk sample. Other parameters calculated by 196 Phoenix analysis of milk excretion data included: Percent recovered (cumulative amount of 197 drug eliminated expressed as percentage of administered dose), $\lambda z$ (first order rate 198 constant associated with the terminal portion of the curve), $\mathrm{T}_{1 / 2 \mathrm{\lambda z}}$ (terminal half-life), 199 area under the time- milk concentration curve from time zero to infinity $\left(\mathrm{AUC}_{0-\infty}\right)$, 200 maximum plasma concentration $\left(\mathrm{C}_{\max }\right)$, and time to maximum plasma concentration $201\left(\mathrm{~T}_{\max }\right)$. 


\section{Milk clearance calculation}

203

204

205

206

207

208

209

210

211

212

213

214

215

216

217

218

219

220

221

222
To determine whether the rate of milk excretion was linearly related to plasma drug concentration, the milk excretion rate $(\Delta \mathrm{A} / \Delta \mathrm{t})$ was plotted against the plasma drug concentration at the mid-point between the two sampling times $\left(C_{\text {mid }}\right.$, calculated by averaging the plasma drug concentrations that were measured at the current and preceding sampling times). In addition, the slope of the regression line drawn through the points of this graph represents the drugs' milk clearance $\left(\mathrm{CL}_{M} / \mathrm{F}\right)$ (Tucker $\left.G T, 1981\right)$ and was calculated using Equation 2.

$$
C L_{M}=\frac{\Delta A / \Delta t}{C_{\text {mid }}}
$$

Equation 2

\section{Results}

Figure 1 is a plot of the means ( \pm standard error) of both plasma and milk concentrationtime profile for gabapentin administered orally at two dose rates of $10 \mathrm{mg} / \mathrm{kg}$ and 20 $\mathrm{mg} / \mathrm{kg}$. Table 1 is a summary of the non-compartmental pharmacokinetic analysis for gabapentin at $10 \mathrm{mg} / \mathrm{Kg}$ and Table 2 is a summary of the non-compartmental pharmacokinetic analysis for gabapentin at $20 \mathrm{mg} / \mathrm{Kg}$ dose rates in both milk and plasma. The mean ( $\pm \mathrm{SD}$ ) plasma $\mathrm{C}_{\max }$ and $\mathrm{T}_{\max }$ for gabapentin administered at 10 $\mathrm{mg} / \mathrm{kg}$ P.O. were $2.87 \pm 0.2 \mu \mathrm{g} / \mathrm{ml}$ and $8.0 \pm 0.0$ hours respectively while for higher dose $\left(20 \mathrm{mg} / \mathrm{kg}\right.$ ) the mean $( \pm \mathrm{SD})$ plasma $\mathrm{C}_{\max }$ and $\mathrm{T}_{\max }$ were $5.42 \pm 0.69 \mu \mathrm{g} / \mathrm{ml}$ and $9.33 \pm$ 3.27 hours respectively. On the other hand, the mean $\left( \pm S D\right.$ ) milk $C_{\max }$ and $T_{\max }$ for gabapentin administered at $10 \mathrm{mg} / \mathrm{kg}$ P.O. were $0.63 \pm 0.13 \mu \mathrm{g} / \mathrm{ml}$ and $12 \pm 6.69$ hours 
223 respectively while for higher dose $(20 \mathrm{mg} / \mathrm{kg})$ the mean $( \pm \mathrm{SD})$ milk $\mathrm{C}_{\max }$ and $\mathrm{T}_{\max }$ were $2241.19 \pm 0.14 \mu \mathrm{g} / \mathrm{ml}$ and $12 \pm 4.4$ hours respectively.

225 Figure 2 is a plot of the means ( \pm standard error) of both plasma and milk concentration226 time profile for meloxicam administered orally at a dose of $1 \mathrm{mg} / \mathrm{kg}$. Table 3 is a 227 summary of various pharmacokinetic parameters in both milk and plasma following non228 compartmental analysis for meloxicam. The mean ( \pm SD) plasma $C_{\max }$ and $T_{\max }$ for 229 meloxicam $(1 \mathrm{mg} / \mathrm{kg}$ ) were $2.89 \pm 0.48 \mu \mathrm{g} / \mathrm{ml}$ and $11.33 \pm 4.12$ hours respectively while 230 the mean $( \pm \mathrm{SD})$ milk $\mathrm{C}_{\max }$ and $\mathrm{T}_{\max }$ were $0.41 \pm 0.16 \mu \mathrm{g} / \mathrm{ml}$ and $9.33 \pm 3.11$ hours 231 respectively.

232 Figures 1-3 shows the calculation of $\mathrm{Cl}_{\mathrm{M}} / \mathrm{F}$ for meloxicam and gabapentin by calculating 233 the average slopes of the regression lines drawn through the milk excretion rate versus 234 plasma drug concentration plots. The mean \pm SD milk clearance for meloxicam was $235166.52 \pm 82.15 \mathrm{~mL} / \mathrm{h}$ while for gabapentin at $10 \mathrm{mg} / \mathrm{kg}$ and $20 \mathrm{mg} / \mathrm{kg}$ were $300.48 \pm$ 23657.4 and $259.57 \pm 102.82 \mathrm{~mL} / \mathrm{h}$ respectively. Since $\mathrm{CL}_{\mathrm{M}} / \mathrm{F}$ was not significantly different 237 between the two gabapentin dose rates, these were combined in Figure 3 to simplify the 238 graph. Milk concentrations depleted below measurable concentrations within 80 hours

240 for meloxicam and 48 and 64 hours for the low and high dose of gabapentin, 241 respectively. Milk to plasma (M/P) ratio was calculated as a measure of the ratio of $242 \mathrm{AUC}_{0-t}(\mathrm{milk})$ over $\mathrm{AUC}_{0-t}$ (plasma) to determine the extent of concentration of the given 243 drugs in milk. The mean \pm SD M/P ratio for meloxicam was $0.14 \pm 0.04$ while 244 gabapentin (for combined dose rates) was $0.23 \pm 0.06$ (Tables 1, 2 and 3). The 
245 percentage of meloxicam excreted in milk when given at $1 \mathrm{mg} / \mathrm{kg} \mathrm{P.O} \mathrm{was} 1.61 \pm 0.76$

$246 \%$ while $0.18 \pm 0.02 \%$ and $0.17 \pm 0.05 \%$ of gabapentin excreted into the milk when

247 given at 10 and $20 \mathrm{mg} / \mathrm{kg}$ respectively. The average milk production rate was $980 \pm 290$ $248 \mathrm{~mL} /$ hour.

\section{Discussion}

251 Lactation did not appear to alter the plasma pharmacokinetics of either meloxicam or 252 gabapentin. The pharmacokinetic parameters from this study are comparable to those 253 previously reported for ruminant beef calves (Coetzee, Mosher et al. 2010). Meloxicam 254 and gabapentin crossed from the plasma into the milk following oral administration at 255 clinically relevant doses. For both drugs, milk concentrations depleted to concentrations 256 that were below the level of detection of the analytical technique within approximately 3 257 days. Milk concentrations that are safe for human consumption have not been 258 established for either of these drugs in the United States, but a maximum residue limit 259 (MRL) has been established in Europe for meloxicam. The level of quantitation of the 260 analytical technique in milk for meloxicam $(10 \mathrm{ng} / \mathrm{ml})$ used in this study is lower than the 261 maximum MRL set by the European Agency for the Evaluation of Medicinal Products $262(15 \mathrm{ng} / \mathrm{ml})$ (www.ema.europa.eu).

$\mathrm{CL}_{\mathrm{M}} / \mathrm{F}$ was low $(\sim 0.2-0.3 \mathrm{~L} / \mathrm{h})$ for both meloxicam and gabapentin when compared to 264 total body clearance (CL/F $\sim 10 \mathrm{~L} / \mathrm{h}$ for meloxicam and $\sim 150 \mathrm{~L} / \mathrm{h}$ for gabapentin) and 265 mammary tissue blood flow in the lactating cow $(\sim 120 \mathrm{~L} / \mathrm{h})$. This suggests that the 266 mammary gland is inefficient in extracting these drugs from the plasma. Less than 1 and 
$2672 \%$ of the administered dose was excreted from the animals' bodies through the milk for 268 gabapentin and meloxicam, respectively.

269 Two different doses of gabapentin were administered to the animals to determine 270 whether saturable transport across either the gastrointestinal or mammary epithelial 271 barriers at 10 and $20 \mathrm{mg} / \mathrm{kg}$ PO would result in non-linear pharmacokinetics. Doubling

272 the dose resulted in a dose-proportional increase in milk and plasma concentrations, 273 whilst the milk clearance remained constant. This suggests that, if the movement of 274 gabapentin across either of these epithelia is facilitated by a transporter, the system 275 was not saturated under the circumstances of this study (doses up to $20 \mathrm{mg} / \mathrm{kg} \mathrm{PO}$ ).

The percentage of the administered gabapentin dose that was excreted through 277 the milk was approximately a tenth lower than for meloxicam. This is despite gabapentin 278 having a higher milk clearance and milk to plasma ratio. The most likely reason for this 279 difference is a lower oral bioavailability for gabapentin. Further studies comparing oral 280 absorption to intravenous pharmacokinetics for this drug would be needed to confirm 281 this hypothesis.

In summary, milk gabapentin and meloxicam concentrations were directly related 283 to plasma concentrations. There was no apparent delay in the appearance of these 284 drugs in the milk, and their rate of depletion from the milk was similar to that from 285 plasma. Neither of the drugs appears to have been sequestered in the mammary tissue 286 or milk. The results of this study suggest that milk from treated cows will have low drug 287 residue concentration soon after plasma drug concentrations have fallen below effective 
288 levels. This study further supports the feasibility of using these drugs for the control of 289 pain in food-producing animals, but efficacy studies are needed.

291 Acknowledgements

292 This project was supported by NIH Grant Number P20RR017686 from the National

293 Center for Research Resources (NCRR). The content is solely the responsibility of the 294 authors and does not necessarily represent the official views of the National Center for 295 Research Resources or the National Institutes of Health

296 The authors would also like to thank College of Veterinary Medicine at Kansas State 297 University and Mr. Michael Scheffel of KSU Dairy Unit.

\section{References}

Brideau, C., C. Van Staden, et al. (2001). "In vitro effects of cyclooxygenase inhibitors in 301 whole blood of horses, dogs, and cats." Am J Vet Res 62(11): 1755-60. 304 gabapentin." J Pharmacol Sci 100(5): 471-86. http://www.ema.europa.eu/docs/en_GB/document_library/Maximum_Residue_Limits_307 _Report/2009/11/WC500014953.pdf 
309 Coetzee, J. F., R. A. Mosher, et al (2010). "Pharmacokinetics of oral gabapentin alone

310 or co-administered with meloxicam in ruminant beef calves." Vet $\mathrm{J}$.

312 Flower, F. C., M. Sedlbauer, et al. (2008). "Analgesics improve the gait of lame dairy

313 cattle." J Dairy Sci 91(8): 3010-4.

314

315 Hurley, R. W., D. Chatterjea, et al. (2002). "Gabapentin and pregabalin can interact

316 synergistically with naproxen to produce antihyperalgesia." Anesthesiology 97(5): 1263-

31773.

318

319 Lazer, E. S., C. K. Miao, et al. (1997). "Effect of structural modification of enol-

320 carboxamide-type nonsteroidal antiinflammatory drugs on COX-2/COX-1 selectivity." $\underline{\mathrm{J}}$

321 Med Chem 40(6): 980-9.

322

323 Ley, S. J., A. E. Waterman, et al. (1996). "Measurement of mechanical thresholds, 324 plasma cortisol and catecholamines in control and lame cattle: a preliminary study." Res 325 Vet Sci 61(2): 172-3.

326

327 Ogino, K., K. Hatanaka, et al. (1997). "Evaluation of pharmacological profile of 328 meloxicam as an anti-inflammatory agent, with particular reference to its relative 329 selectivity for cyclooxygenase-2 over cyclooxygenase-1." Pharmacology 55(1): 44-53. 
331 Picazo, A., G. Castaneda-Hernandez, et al. (2006). "Examination of the interaction

332 between peripheral diclofenac and gabapentin on the $5 \%$ formalin test in rats." Life Sci

$333 \quad 79(24): 2283-7$.

334

335 Sivenius, J., R. Kalviainen, et al. (1991). "Double-blind study of Gabapentin in the

336 treatment of partial seizures." Epilepsia 32(4): 539-42.

337

338 Su, T. Z., E. Lunney, et al. (1995). "Transport of gabapentin, a gamma-amino acid drug,

339 by system I alpha-amino acid transporters: a comparative study in astrocytes,

340 synaptosomes, and CHO cells." J Neurochem. 64(5): 2125-31.

341

342 Taylor, C. P. (2009). "Mechanisms of analgesia by gabapentin and pregabalin--calcium

343 channel alpha2-delta [Cavalpha2-delta] ligands." Pain 142(1-2): 13-6.

344

345 Tucker, G.T. (1981). " Measurement of the renal clearance of drugs." Br. J. Clin.

346 Pharmac. 12: 761-770.

347

348 U.S. Food and Drug Administration (2007) Pasturized Milk

349 Ordinance http://www.fda.gov/Food/FoodSafety/Product-

350 Specificlnformation/MilkSafety/NationalConferenceonInterstateMilkShipmentsNCIMSMo

351 delDocuments/PasteurizedMilkOrdinance2007/ucm063876.htm

352

353 
354 Whay, H. R., D. C. Main, et al. (2003). "Assessment of the welfare of dairy cattle using 355 animal-based measurements: direct observations and investigation of farm records."

356 Vet Rec 153(7): 197-202.

357

358 Whay, H. R., A. E. Waterman, et al. (1998). "The influence of lesion type on the duration 359 of hyperalgesia associated with hindlimb lameness in dairy cattle." Vet J 156(1): 23-9.

360

361 Woolf, C. J. and R. J. Mannion (1999). "Neuropathic pain: aetiology, symptoms,

362 mechanisms, and management." Lancet 353(9168): 1959-64.

363

364 Zhang, Y., M. Huo, et al. (2010). "PKSolver: An add-in program for pharmacokinetic and 365 pharmacodynamic data analysis in Microsoft Excel." Comput Methods Programs

366 Biomed 99(3): 306-14.

367

368

369

370

371

372

373

374

375

376 
$377 \quad$ Figures

378

<Figure 1>

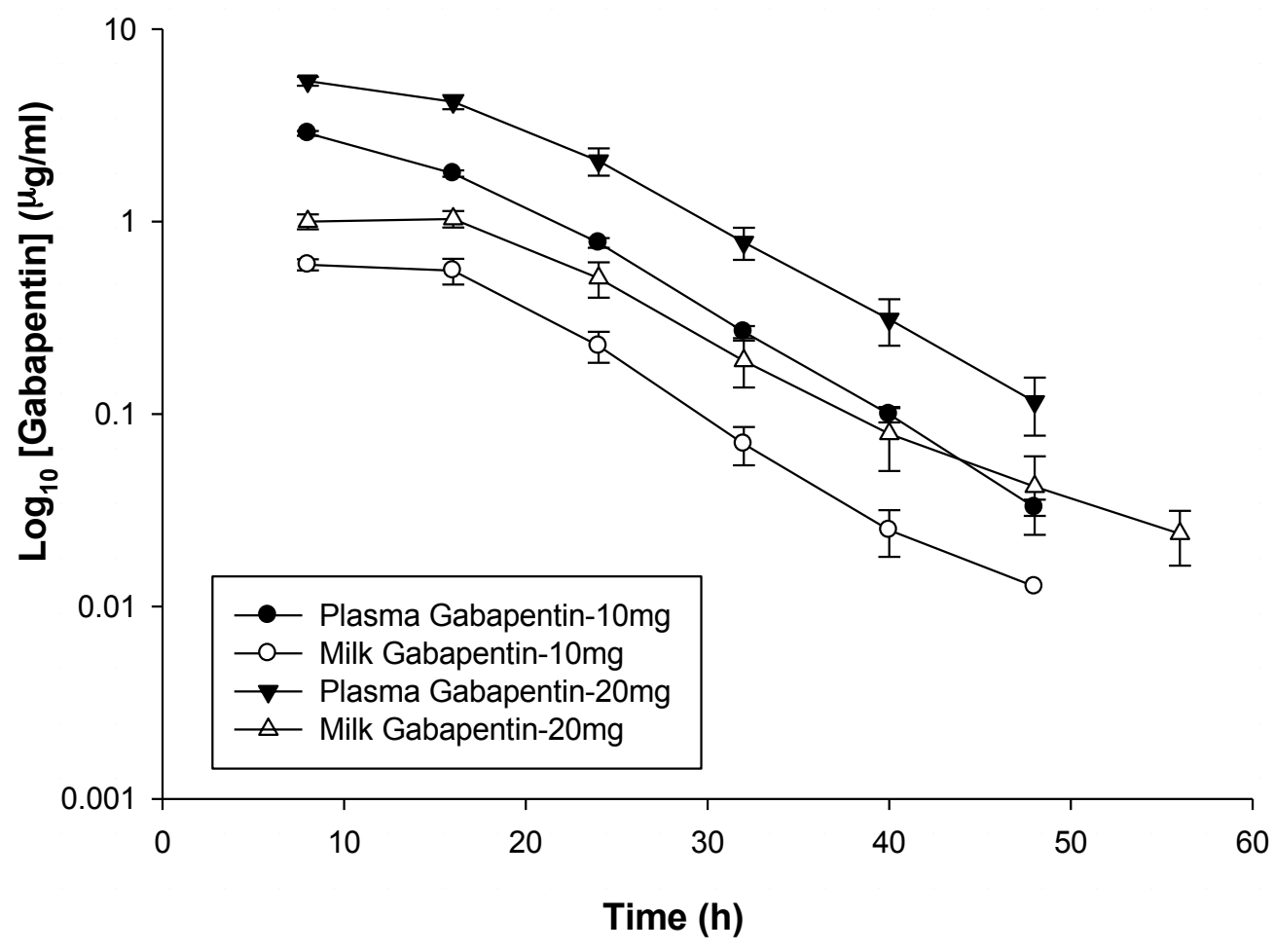

380

Figure 1. Mean plasma and milk concentrations of Gabapentin following 10 and 20

381 $\mathrm{mg} / \mathrm{kg} \mathrm{PO}$ administration. 


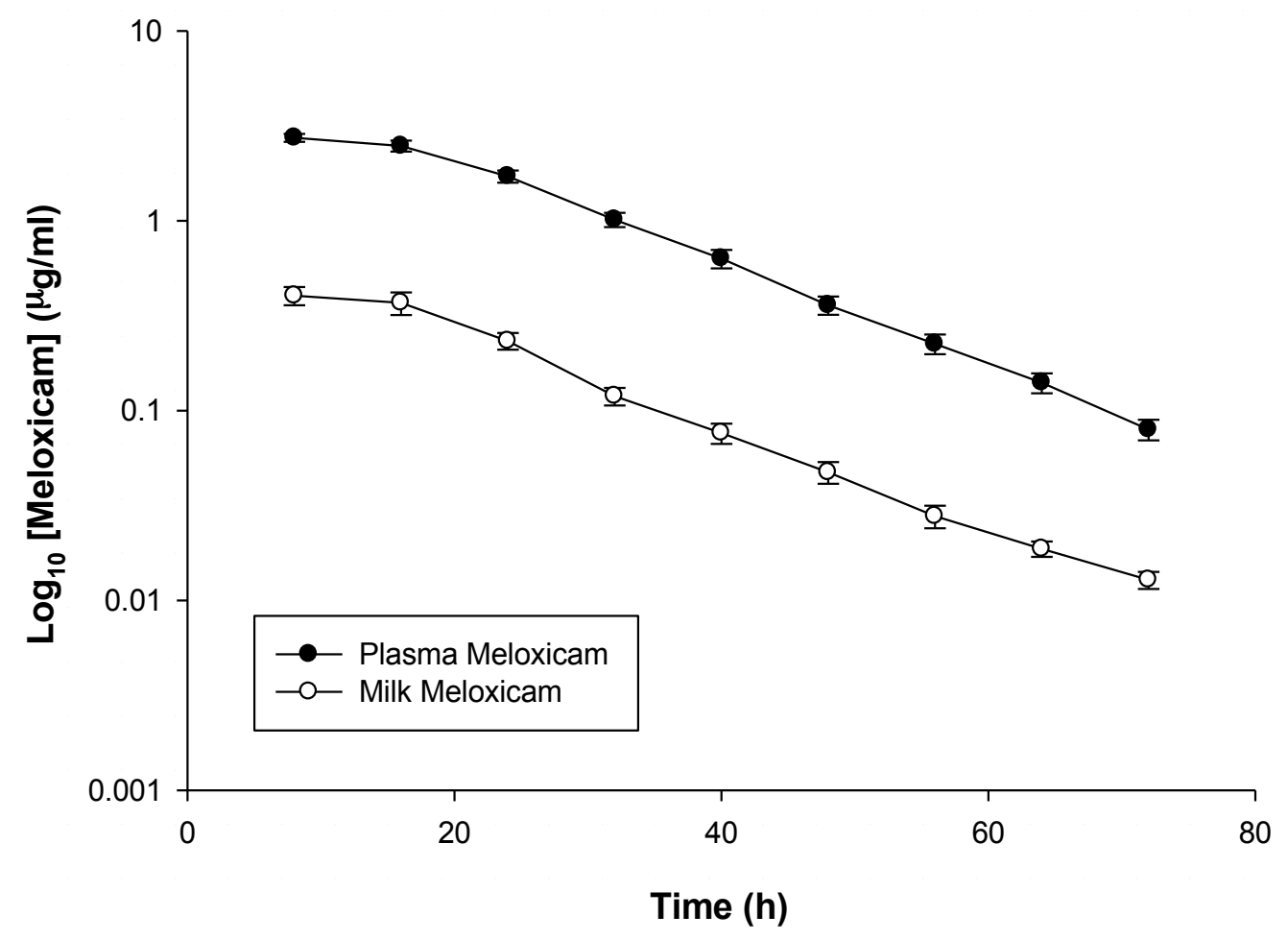

392 Figure 2. Mean plasma and milk concentrations of Meloxicam following $1 \mathrm{mg} / \mathrm{kg} \mathrm{PO}$ 393 administration.

394

395

396 


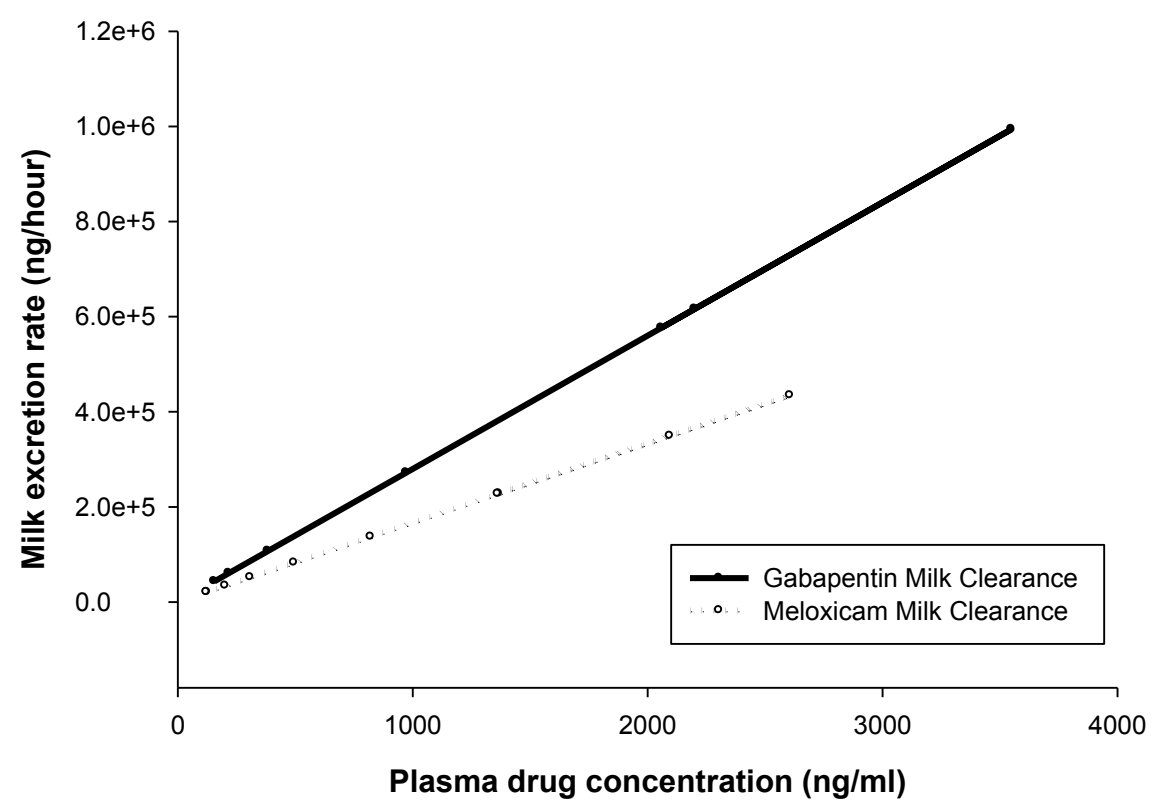

Plasma drug concentration $(\mathrm{ng} / \mathrm{ml})$

405 Figure 3. Average slopes of the regression lines drawn through the milk excretion rate 406 versus plasma drug concentration plots for meloxicam and gabapentin, representing the 407 milk clearance of these two drugs. 
TABLE 3 Meloxicam Milk and Plasma non-compartmental Pharmacokinetic Parameters following PO Administration at $1 \mathrm{mg} / \mathrm{kg}$

\begin{tabular}{|c|c|c|c|c|c|c|c|c|c|c|c|}
\hline \multirow{3}{*}{ Parameters } & \multirow{3}{*}{ Units } & \multicolumn{10}{|c|}{ Meloxicam $1 \mathrm{mg} / \mathrm{kg}$ (targeted dose) } \\
\hline & & \multicolumn{5}{|c|}{ Milk } & \multicolumn{5}{|c|}{ Plasma } \\
\hline & & Mean & STDEV & Min & Median & Max & Mean & STDEV & Min & Median & Max \\
\hline$\lambda z$ & $1 / \mathrm{h}$ & 0.07 & 0.01 & 0.06 & 0.07 & 0.08 & 0.06 & 0.02 & 0.01 & 0.06 & 0.08 \\
\hline$t_{1 / 2}$ & $\mathrm{~h}$ & 10.38 & 1.20 & 8.25 & 10.62 & 12.41 & 14.58 & 11.32 & 8.58 & 11.69 & 50.29 \\
\hline$T_{\max }$ & $\mathrm{h}$ & 9.33 & 3.11 & 8.00 & 8.00 & 16.00 & 11.33 & 4.12 & 8.00 & 8.00 & 16.00 \\
\hline$C_{\max }$ & $\mu \mathrm{g} / \mathrm{ml}$ & 0.41 & 0.16 & 0.25 & 0.36 & 0.76 & 2.89 & 0.48 & 2.18 & 2.97 & 3.64 \\
\hline$C_{0}$ & $\mu \mathrm{g} / \mathrm{ml}$ & 0.46 & 0.16 & 0.27 & 0.42 & 0.72 & 3.43 & 1.60 & 2.11 & 2.71 & 7.79 \\
\hline $\mathrm{AUC}_{0-t}$ & $\mu \mathrm{g} /\left.\mathrm{ml}\right|^{\star} \mathrm{h}$ & 12.15 & 4.36 & 5.84 & 11.05 & 21.25 & 89.45 & 16.93 & 65.16 & 86.65 & 119.52 \\
\hline$A \cup C_{0-\infty}$ & $\mu \mathrm{g} / \mathrm{ml}^{*} \mathrm{~h}$ & 12.34 & 4.39 & 5.96 & 11.22 & 21.50 & 89.99 & 16.91 & 65.53 & 87.07 & 119.99 \\
\hline $\mathrm{AUMC}_{0-\infty}$ & $\mu \mathrm{g} / \mathrm{ml}^{\star} \mathrm{h}^{2}$ & & & & & & 1768.71 & 477.06 & 1016.02 & 1733.20 & 2690.31 \\
\hline MRT & $\mathrm{h}$ & & & & & & 19.46 & 2.54 & 14.18 & 19.60 & 22.42 \\
\hline $\mathrm{CL} / \mathrm{F}$ & $\mathrm{mL} / \mathrm{h}$ & & & & & & 9944.72 & 1961.75 & 6071.01 & 9710.86 & 14092.62 \\
\hline $\mathrm{CL}_{M} / \mathrm{F}$ & $\mathrm{mL} / \mathrm{h}$ & 166.52 & 82.15 & 64.10 & 163.10 & 374.20 & & & & & \\
\hline Percent $t_{\text {recovered }}$ & $\%$ & 1.61 & 0.76 & 0.97 & 1.44 & 3.69 & & & & & \\
\hline $\mathrm{AUC}_{0-t}\left(\right.$ Milk)/AUC $\mathrm{C}_{0-t}$ (Plasma) & & 0.14 & 0.04 & 0.08 & 0.13 & 0.21 & & & & & \\
\hline
\end{tabular}


TABLE 1 Gabapentin Milk and Plasma non-compartmental Pharmacokinetic Parameters following PO Administration at $10 \mathrm{mg} / \mathrm{kg}$

\begin{tabular}{|c|c|c|c|c|c|c|c|c|c|c|c|}
\hline \multirow{3}{*}{ Parameters } & \multirow{3}{*}{ Units } & \multicolumn{10}{|c|}{ Gabapentin 10 mg/kg (targeted dose) } \\
\hline & & \multicolumn{5}{|c|}{ Milk } & \multicolumn{5}{|c|}{ Plasma } \\
\hline & & Mean & STDEV & Min & Max & Median & Mean & STDEV & Min & Max & Median \\
\hline$\lambda z$ & $1 / \mathrm{h}$ & 0.15 & 0.02 & 0.14 & 0.19 & 0.15 & 0.13 & 0.014 & 0.11 & 0.15 & 0.13 \\
\hline$t_{1 / 2}$ & $\mathrm{~h}$ & 4.54 & 0.53 & 3.60 & 4.99 & 4.71 & 5.50 & 0.63 & 4.74 & 6.56 & 5.43 \\
\hline$T_{\max }$ & $\mathrm{h}$ & 12.00 & 6.69 & 8.00 & 24.00 & 8.00 & 8.00 & 0.00 & 8.00 & 8.00 & 8.00 \\
\hline$C_{\max }$ & $\mu \mathrm{g} / \mathrm{ml}$ & 0.63 & 0.13 & 0.47 & 0.78 & 0.64 & 2.87 & 0.20 & 2.61 & 3.22 & 2.87 \\
\hline$C_{0}$ & $\mu \mathrm{g} / \mathrm{ml}$ & 0.71 & 0.08 & 0.61 & 0.81 & 0.72 & 4.71 & 0.81 & 3.36 & 5.54 & 4.91 \\
\hline$A \cup C_{0-t}$ & $\mu g / m l^{*} h$ & 15.48 & 5.40 & 9.90 & 25.12 & 15.16 & 65.35 & 3.86 & 61.91 & 72.62 & 63.98 \\
\hline$A \cup C_{0-\infty}$ & $\mu g / m l^{*} h$ & 15.60 & 5.40 & 10.01 & 25.22 & 15.26 & 65.59 & 3.84 & 62.29 & 72.85 & 64.21 \\
\hline $\mathrm{AUMC}_{0-\infty}$ & $\mu \mathrm{g} / \mathrm{ml}^{*} \mathrm{~h}^{2}$ & & & & & & 683.14 & 54.60 & 621.66 & 765.53 & 668.82 \\
\hline MRT & h & & & & & & 10.44 & 0.99 & 9.72 & 12.29 & 9.99 \\
\hline $\mathrm{CL} / \mathrm{F}$ & $\mathrm{mL} / \mathrm{h}$ & & & & & & 156101.41 & 26098.84 & 124358.23 & 183650.18 & 158103.92 \\
\hline $\mathrm{CL}_{M} / F$ & $\mathrm{~mL} / \mathrm{h}$ & 300.48 & 57.40 & 225.10 & 358.00 & 308.70 & & & & & \\
\hline Percent $t_{\text {recovered }}$ & $\%$ & 0.18 & 0.02 & 0.16 & 0.23 & 0.18 & & & & & \\
\hline$A \cup C_{o-t}($ Milk $) / A \cup C_{0-t}$ (Plasma) & & 0.24 & 0.09 & 0.15 & 0.41 & 0.24 & & & & & \\
\hline
\end{tabular}


TABLE 2 Gabapentin Milk and Plasma non-compartmental Pharmacokinetic Parameters following PO Administration at 20 mg/kg

\begin{tabular}{|c|c|c|c|c|c|c|c|c|c|c|c|}
\hline \multirow{3}{*}{ Parameters } & \multirow{3}{*}{ Units } & \multicolumn{10}{|c|}{ Gabapentin 20 mg/kg (targeted dose) } \\
\hline & & \multicolumn{5}{|c|}{ Milk } & \multicolumn{5}{|c|}{ Plasma } \\
\hline & & Mean & STDEV & Min & Median & Max & Mean & STDEV & Min & Median & Max \\
\hline$\lambda z$ & $1 / \mathrm{h}$ & 0.14 & 0.02 & 0.11 & 0.17 & 0.13 & 0.13 & 0.01 & 0.12 & 0.15 & 0.14 \\
\hline$t_{1 / 2}$ & $\mathrm{~h}$ & 5.20 & 0.77 & 4.08 & 6.10 & 5.20 & 5.26 & 0.57 & 4.79 & 6.03 & 4.99 \\
\hline$T_{\max }$ & $\mathrm{h}$ & 12.00 & 4.40 & 8.00 & 16.00 & 12.00 & 9.33 & 3.27 & 8.00 & 16.00 & 8.00 \\
\hline$C_{\max }$ & $\mu \mathrm{g} / \mathrm{ml}$ & 1.19 & 0.14 & 1.01 & 1.35 & 1.23 & 5.42 & 0.69 & 4.07 & 6.04 & 5.57 \\
\hline$C_{0}$ & $\mu \mathrm{g} / \mathrm{ml}$ & 1.22 & 0.46 & 0.69 & 1.86 & 1.25 & 7.31 & 2.45 & 4.21 & 10.51 & 7.24 \\
\hline$A \cup C_{0-t}$ & $\mu \mathrm{g} / \mathrm{ml}{ }^{\star} \mathrm{h}$ & 27.56 & 3.12 & 22.29 & 31.36 & 27.28 & 132.00 & 18.25 & 101.08 & 149.73 & 134.42 \\
\hline $\mathrm{AUC}_{0-\infty}$ & $\mu \mathrm{g} / \mathrm{ml}{ }^{\star} \mathrm{h}$ & 27.71 & 3.13 & 22.36 & 31.50 & 27.46 & 132.31 & 18.33 & 101.24 & 150.10 & 134.69 \\
\hline $\mathrm{AUMC}_{0-\infty}$ & $\mu \mathrm{g} / \mathrm{ml}^{*} \mathrm{~h}^{2}$ & & & & & & 1650.27 & 456.98 & 1195.46 & 2273.30 & 1624.75 \\
\hline MRT & $\mathrm{h}$ & & & & & & 12.38 & 2.37 & 9.38 & 15.15 & 13.10 \\
\hline $\mathrm{CL} / \mathrm{F}$ & $\mathrm{mL} / \mathrm{h}$ & & & & & & 150371.87 & 39531.60 & 104942.90 & 145184.25 & 210949.66 \\
\hline $\mathrm{CL}_{M}$ & $\mathrm{~mL} / \mathrm{h}$ & 259.57 & 102.82 & 152.50 & 424.10 & 249.65 & & & & & \\
\hline Percent recovered & $\%$ & 0.17 & 0.05 & 0.11 & 0.25 & 0.16 & & & & & \\
\hline$A \cup C_{0-t}($ Milk $) / A \cup C_{0-t}$ (Plasma) & & 0.21 & 0.03 & 0.18 & 0.27 & 0.21 & & & & & \\
\hline
\end{tabular}

